\title{
Analysis Scientific Attitudes in the Implementation of Science-Biology Learning Practicum for Class VIII Students in SMPN 34 Padang
}

\section{Analisis Sikap Ilmiah dalam Pelaksanaan Praktikum Pembelajaran IPA-Biologi Peserta Didik Kelas VIII SMPN 34 Padang}

\author{
Tiffany Mantoviana ${ }^{1)}$, Azwir Anhar ${ }^{1)}$, Zulyusri ${ }^{1)}$, Ristiono ${ }^{1)}$ \\ 1) Jurusan Biologi, FMIPA, Universitas Negeri Padang \\ Jl. Prof. Dr. Hamka Air Tawar, Padang, Sumatera Barat, Indonesia \\ Email: tiffanymantoviana7@gmail.com
}

\begin{abstract}
Scientific attitude is a collection of several important aspects that describe the interaction of each student. This study aims to study the quality of scientific attitudes carried out by students when carrying out practical learning in Class VIII SMPN 34 Padang. The aspects of scientific thought discussed include: 1) curiosity, 2) respect for data, 3) critical thinking, 4) discovery and creativity, 5) open thinking and working together, 6) perseverance, and 7) sensitive to Surrounding environment. This type of research is a descriptive study, with a total of 280 students and a sample of 108 students consisting of 9 classes. Sampling using Proportional Cluster Random Sampling technique by taking $\pm 40 \%$ of the total population. Data collection using questionnaires and observation sheets. Data analysis was performed quantitatively with the percentage analysis method. From this study obtained research on scientific quality assessment on every aspect of the aspect curiosity has good criteria, aspects of respect for data that have adequate criteria, critical aspects of thinking have sufficient criteria, aspects of discovery and considerations that have good quality, aspects of open thinking and working together have good criteria, perseverance aspects have good criteria, and aspects that are sensitive to the environment have criteria. So, the quality of scientific thinking of students in the implementation of science-biology learners.
\end{abstract}

Keywords: Scientific attitude, Practicum

\section{PENDAHULUAN}

Berdasarkan hakikatnya, IPA meliputi produk, proses dan sikap. IPA sebagai produk akan mencakup konsep, hukum, dan teori yang dikembangkan sebagai kebutuhan manusia, IPA sebagai proses yaitu sejumlah keterampilan untuk mengkaji fenomena alam dengan cara tertentu untuk memperoleh ilmu dan pengembangan ilmu selanjutnya, dan IPA sebagai sikap yaitu menunjukkan nilai-nilai yang muncul 
ketika proses sains dilakukan yang biasanya disebut sebagai sikap ilmiah (Farooq, 2012:381).

Pembelajaran IPA tidak cukup dengan penjelasan dan mendengarkan saja, melainkan peserta didik akan lebih mudah memahami materi dan konsep-konsep jika dilakukan dengan kegiatan menemukan konsep itu sendiri. Proses belajar mengajar IPA lebih diarahkan pada pendekatan keterampilan proses, sehingga peserta didik dapat menemukan fakta, menerapkan konsep, teori dan sikap ilmiah yang pada akhirnya dapat berpengaruh positif terhadap kualitas produk pendidikan (Tias, 2017:52).

Dalam proses pembelajaran IPA, diperlukan suatu metode yang dapat membekali peserta didik untuk mencapai kompetensi yang diharapkan Kurikulum 2013. Suatu metode yang dapat digunakan adalah metode praktikum. Kegiatan praktikum yang dilakukan dapat membuat peserta didik mampu menguasai konsep, fakta dan proses sains sehingga meningkatkan keterampilan dan sikap ilmiah peserta didik (Suryaningsih, 2017:51). Pelaksanaan praktikum pada pembelajaran IPA merupakan bentuk sederhana dari aspek sikap sains sebagai proses yaitu melakukan kegiatan ilmiah sehingga membangkitkan motivasi peserta didik menjadi seorang ilmuan di masa akan datang.

Sikap ilmiah menjadi aspek sikap yang sangat penting dalam melaksanakan percobaan- percobaan (kegiatan ilmiah sederhana) dan menjadi tolak ukur ketika menjalani kegiatan ilmiah. Menurut penelitian Probowati (2018:9), sikap ilmiah merupakan kumpulan dari beberapa aspek penting yang mencerminkan perilaku dalam diri setiap peserta didik seperti mempunyai rasa ingin tahu, peduli terhadap fakta, mampu berfikir kritis, kreatif, berfikiran terbuka serta mampu menghargai orang lain. Aspek-aspek tersebut penting ditanamkan dalam diri setiap peserta didik untuk mencapai tujuan pembelajaran.

Permasalahan yang terdapat di SMPN 34 Padang pada saat pelaksanaan praktikum IPA yaitu guru mengalami kesulitan dalam mengatur peserta didik apabila proses pembelajaran dalam kegiatan praktikum sehingga dibutuhkan beberapa waktu saat memulai kegiatan praktikum dan belum adanya instrumen penilaian mengenai sikap ilmiah terhadap peserta didik saat kegiatan pelaksanaan praktikum, sehingga guru hanya berfokus kepada penilaian proses peserta didik. Beberapa faktor tersebut yang menjadi penyebab guru belum mengetahui aspek-aspek sikap ilmiah apa saja yang telah dilakukan peserta didik saat pelaksanaan praktikum.

\section{METODE PENELITIAN}

Penelitian ini merupakan jenis penelitian deskriptif. Populasi penelitian adalah seluruh peserta didik kelas VIII SMPN 34 Padang tahun pelajaran 2019/2020 berjumlah 280 orang peserta didik. Jumlah sampel dalam penelitian ini yaitu 108 orang peserta didik dengan menggunakan teknik pengambilan sampel Proportional Cluster Random Sampling. Variabel dalam penelitian ini adalah sikap 
ilmiah peserta didik kelas VIII SMPN 34 Padang tahun pelajaran 2019/2020. Teknik pengumpulan data yaitu dengan pemberian angket terhadap peserta didik dan lembar observasi. Analisis data dilakukan secara kuantitatif dengan metode analisis persentase.

$$
\text { Rumus: } \quad \mathrm{P}=\frac{F}{N} \times 100 \%
$$

Keterangan:

$$
\begin{array}{ll}
\mathrm{P} & =\text { Persentase } \\
\mathrm{F} & =\text { Frekuensi } \\
\mathrm{N} & =\text { Jumlah Sampel }
\end{array}
$$

Rumus ini dikembangkan menjadi:

$$
\text { Capaian }=\frac{\text { skor diperoleh }}{\text { skor maksimal }} \times 100 \%
$$

Kriteria penilaian sikap yang digunakan ditampilkan pada Tabel 1.

Tabel 1. Kriteria Penilaian

\begin{tabular}{ccc}
\hline No. & Kategori & Persentase $(\%)$ \\
\hline 1. & Sangat baik & $81-100$ \\
\hline 2. & Baik & $61-80$ \\
\hline 3. & Cukup & $41-60$ \\
\hline 4. & Kurang & $21-40$ \\
\hline 5. & Kurang sekali & $0-20$ \\
\hline
\end{tabular}

Sumber: Riduwan (2005: 89)

\section{HASIL PENELITIAN DAN PEMBAHASAN}

\section{Hasil Analisis Data}

Hasil analisis data ditinjau dari persentase sikap ilmiah peserta didik dalam pelaksanaan praktikum pembelajaran IPA-Biologi berdasarkan angket dan lembar observasi sebagai berikut.

Persentase aspek sikap ilmiah peserta didik saat pelaksanaan praktikum pembelajaran IPA-Biologi berdasarkan hasil analisis data angket terdapat pada Tabel 2.

Persentase aspek sikap ilmiah peserta didik saat pelaksanaan praktikum pembelajaran IPA-Biologi berdasarkan hasil analisis data lembar observasi terdapat pada Tabel 3. 
Tabel 2. Persentase Sikap Ilmiah Peserta Didik dalam Pelaksanaan Praktikum Pembelajaran IPA-Biologi Berdasarkan Hasil Analisis Data Angket

\begin{tabular}{cccccccc}
\hline Kelas & \multicolumn{7}{c}{ Persentase Aspek Sikap Ilmiah (\%) } \\
\cline { 2 - 7 } VIII & $\mathrm{A}$ & $\mathrm{B}$ & $\mathrm{C}$ & $\mathrm{D}$ & $\mathrm{E}$ & $\mathrm{F}$ & $\mathrm{G}$ \\
\hline 1 & 82,29 & 76,04 & 68,75 & 73,95 & 76,04 & 83,33 & 84,37 \\
\hline 2 & 76,13 & 71,59 & 67,04 & 63,63 & 81,81 & 80,20 & 82,95 \\
\hline 3 & 76,04 & 70,83 & 73,95 & 62,5 & 70,83 & 76,04 & 83,33 \\
\hline 4 & 77,08 & 61,45 & 77,08 & 63,54 & 71,87 & 79,16 & 81,25 \\
\hline 5 & 77,08 & 79,16 & 75 & 68,75 & 68,75 & 82,29 & 85,41 \\
\hline 6 & 81,25 & 69,79 & 70,83 & 66,66 & 77,08 & 81,25 & 81,25 \\
\hline 7 & 75 & 72,91 & 68,75 & 64,58 & 57,29 & 77,08 & 80,20 \\
\hline 8 & 79,16 & 70,83 & 73,95 & 69,79 & 75 & 81,25 & 86,45 \\
\hline 9 & 72,91 & 72,91 & 69,79 & 63,54 & 72,91 & 80,20 & 87,5 \\
\hline $\begin{array}{c}\text { Rata- } \\
\text { rata(\%) }\end{array}$ & 77,31 & 71,99 & 71,87 & 66,43 & 72,45 & 80,09 & 83,79 \\
\hline
\end{tabular}

Tabel 3. Persentase Sikap Ilmiah Peserta Didik dalam Pelaksanaan Praktikum Pembelajaran IPA-Biologi Berdasarkan Hasil Analisis Data Lembar Observasi

\begin{tabular}{cccccccc}
\hline \multirow{2}{*}{$\begin{array}{c}\text { Kelas } \\
\text { VIII }\end{array}$} & \multicolumn{7}{c}{ Persentase Aspek Sikap Ilmiah (\%) } \\
\cline { 2 - 8 } & $\mathrm{A}$ & $\mathrm{B}$ & $\mathrm{C}$ & $\mathrm{D}$ & $\mathrm{E}$ & $\mathrm{F}$ & $\mathrm{G}$ \\
\hline 1 & 60,41 & 60,41 & 50 & 50 & 52,08 & 64,58 & 68,75 \\
\hline 2 & 52,08 & 50 & 39,58 & 50 & 58,33 & 60,41 & 70,83 \\
\hline 3 & 54,16 & 47,91 & 39,58 & 52,08 & 60,41 & 62,5 & 66,66 \\
\hline 4 & 50 & 45,83 & 43,75 & 50 & 56,25 & 58,33 & 64,58 \\
\hline 5 & 52,08 & 50 & 43,75 & 52,08 & 56,25 & 58,33 & 62,5 \\
\hline 6 & 52,08 & 39,58 & 37,5 & 50 & 56,25 & 50 & 64,58 \\
\hline 7 & 54,16 & 45,83 & 58,33 & 58,33 & 47,91 & 58,33 & 62,5 \\
\hline 8 & 54,16 & 47,91 & 45,83 & 54,16 & 43,75 & 52,08 & 56,25 \\
\hline 9 & 54,16 & 50 & 43,75 & 47,91 & 52,08 & 50 & 62,5 \\
\hline $\begin{array}{c}\text { Rata- } \\
\text { rata(\%) }\end{array}$ & 53,70 & 48,61 & 44,67 & 51,62 & 53,70 & 57,17 & 64,35 \\
\hline Keteryyyyyyyyyyyyyy
\end{tabular}

Keterangan Aspek :
A : Rasa ingin tahu;
B : Respek terhadap data;
$\mathrm{C}$ : Berpikir kritis;
D : Penemuan dan kreativitas;
E : Berpikir terbuka dan kerjasama;
F : Ketekunan;
$\mathrm{H}$ : Peka terhadap lingkungan sekitar.

Berdasarkan hasil analisis data dari angket dan lembar observasi, dapat dilihat total rata-rata persentase dan kriteria sikap ilmiah peserta didik saat pelaksanaan praktikum pembelajaran IPA-Biologi Kelas VIII dari ketujuh aspek yang dinilai pada Tabel 4. dan Gambar 1. 
Tabel 4. Rata-rata Persentase Sikap Ilmiah pada Setiap Aspek Berdasarkan Hasil Analisis Data Angket dan Lembar Observasi

\begin{tabular}{llcccc}
\hline No. & \multicolumn{1}{c}{ Aspek Sikap Ilmiah } & $\begin{array}{c}\text { Angket } \\
(\%)\end{array}$ & $\begin{array}{c}\text { Lembar } \\
\text { Observasi } \\
(\%)\end{array}$ & $\begin{array}{c}\text { Total } \\
(\%)\end{array}$ & Kriteria \\
\hline 1. & Rasa ingin tahu & 77,3148 & 53,7037 & 65,5092 & Baik \\
\hline 2. & Respek terhadap data & 71,9907 & 48,61111 & 60,3009 & Cukup \\
\hline 3. & Berpikir kritis & 71,875 & 44,67593 & 58,2754 & Cukup \\
\hline 4. & Penemuan dan kreativitas & 66,4352 & 51,62037 & 59,0277 & Cukup \\
\hline 5. & Berpikir terbuka dan & 72,4537 & 53,7037 & 63,0787 & Baik \\
& kerjasama & & & Baik \\
\hline 6. & Ketekunan & 80,0926 & 57,17593 & 68,6342 & Baik \\
\hline 7. & Peka terhadap lingkungan & 83,7963 & 64,35185 & 74,0740 & \\
& sekitar & & & Cukup \\
\hline
\end{tabular}

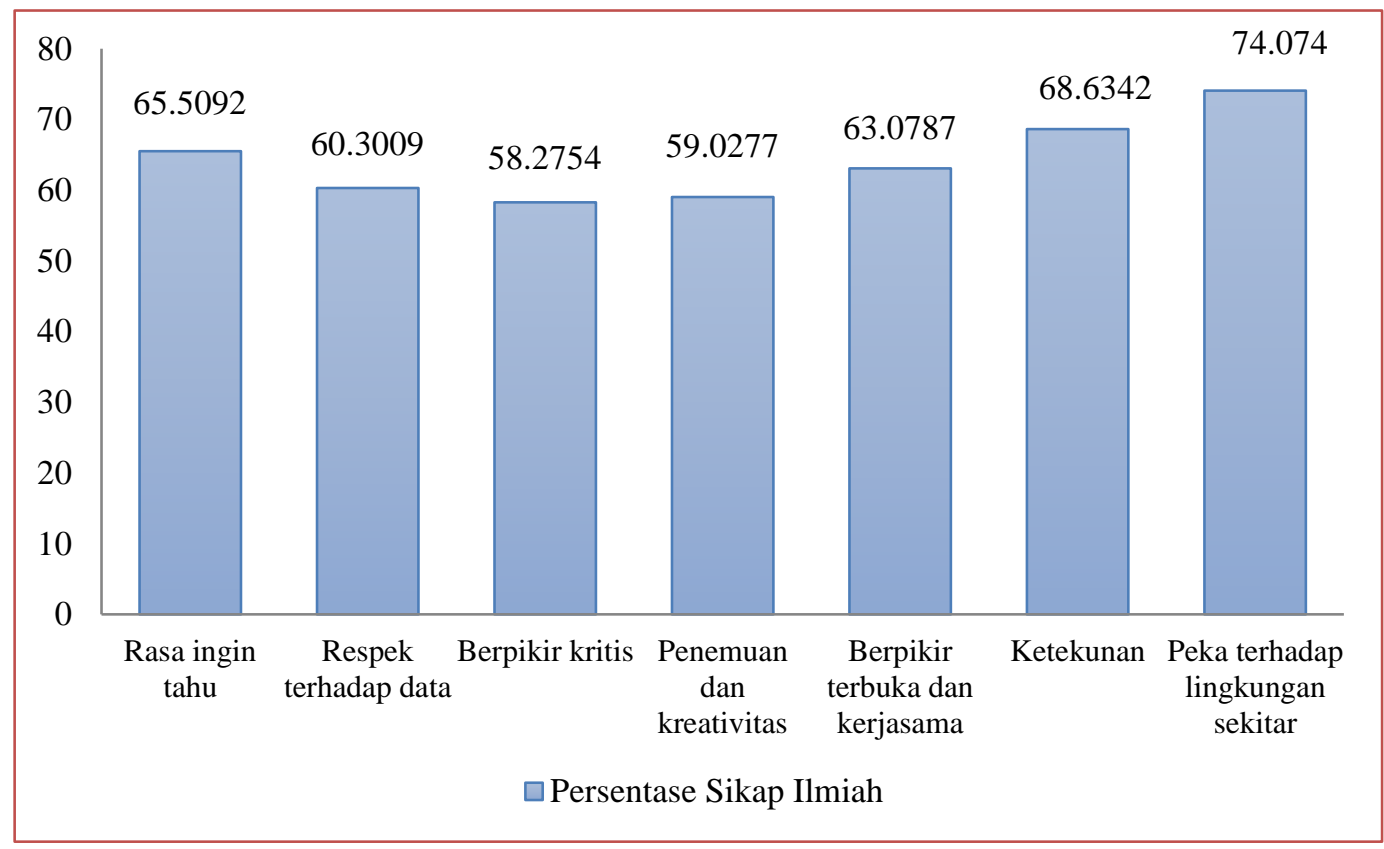

Gambar 1. Rata-rata Persentase Sikap Ilmiah Peserta Didik dalam Pelaksanaan Praktikum Pembelajaran IPA-Biologi Kelas VIII Berdasarkan Hasil Analisis Data Angket dan Lembar Observasi

\section{Pembahasan}

Aspek-aspek sikap ilmiah yang diamati pada peserta didik yaitu aspek rasa ingin tahu, aspek respek terhadap data, aspek berpikir kritis, aspek penemuan dan kreatifitas, aspek berpikir terbuka dan kerjasama, aspek ketekunan, dan aspek peka terhadap lingkungan sekitar. Dari hasil analasis data sikap ilmiah peserta didik dalam 
praktikum, pada angket kriteria sangat baik dan menjadi kriteria paling banyak dimiliki peserta didik, sedangkan pada instrumen lembar observasi kriteria baik menjadi kriteria paling banyak yang dimiliki peserta didik.

Berdasarkan hasil analisis angket dan lembar observasi terhadap sikap ilmiah peserta didik dalam pelaksanaan praktikum, dapat dilihat bahwa dari ketujuh aspek sikap ilmiah peserta didik yang dinilai terdapat empat aspek yang memiliki kriteria baik dan 3 aspek yang memiliki kriteria cukup. Aspek-aspek sikap ilmiah yang memiliki kriteria baik yaitu pada aspek sikap rasa ingin tahu dengan persentase 65,50\%, aspek sikap berpikir terbuka dan kerjasama dengan persentase 63,07\%, aspek sikap ketekunan dengan persentase $68,63 \%$, dan aspek sikap peka terhadap lingkungan sekitar dengan persentase 74,07\%. Aspek-aspek sikap ilmiah yang memiliki kriteria cukup yaitu pada aspek sikap respek terhadap data dengan persentase $60,30 \%$, aspek sikap berpikir kritis dengan persentase $58,27 \%$, dan aspek sikap penemuan dan kreativitas dengan persentase 59,02\%.

Kualitas sikap ilmiah pada aspek rasa ingin tahu kriteria baik dengan persentase $65,5 \%$. Beberapa peserta didik sudah melaksanakan sikap ilmiah dilihat dari empat indikator yang dinilai yaitu antusias mencari jawaban, menanyakan setiap kegiatan, perhatian terhadap kegiatan praktikum, dan antusias pada saat pelaksanaan praktikum. Indikator yang jarang dilaksanakan oleh peserta didik yaitu indikator antusias mencari jawaban, hal ini disebabkan karena kurangnya rasa keingintahuan peserta didik dalam menyelesaikan beberapa permasalahan saat pelaksanaan praktikum sehingga peserta didik kurang antusias dalam melaksanakan indikator tersebut.

Kualitas sikap ilmiah pada aspek respek terhadap data memiliki kriteria cukup dengan persentase $60,3 \%$. Dari empat indikator yang dinilai yaitu objektif terhadap data, mengambil keputusan sesuai fakta, tidak mencampur fakta dengan pendapat, dan tidak memanipulasi data, dapat diketahui bahwa indikator yang paling sering dilaksanakan oleh peserta didik yaitu pada indikator objektif terhadap data yang didapat dan tidak memanipulasi data.

Kualitas sikap ilmiah pada aspek berpikir kritis memiliki kriteria cukup dengan persentase 58,27\%. Pada aspek ini merupakan aspek dengan skor terendah dari ketujuh aspek sikap ilmiah yang dinilai. Dari keempat indikator yang dinilai, yaitu berani mempertahankan kebenaran, tidak tergesa-gesa saat membuat kesimpulan, mengulangi kegiatan yang dilakukan, dan tidak mengabaikan data, hanya indikator tidak mengabaikan data yang paling banyak dilaksanakan. Peserta didik kurang berani mempertahankan kebenaran dan tidak berniat untuk mengulangi kegiatan yang dilakukan ketika terjadi beberapa perbedaan hasil dari kegiatan percobaan atau pengamatan, sehingga sikap berpikir kritis peserta didik kurang terlatih pada aspek ini. 
Kualitas sikap ilmiah pada sikap penemuan dan kreativitas memiliki kriteria cukup dengan persentase 59,02\%. Aspek sikap penemuan dan kreativitas memiliki persentase sedikit lebih tinggi dibandingkan sikap berpikir kritis. Pada aspek ini, peserta didik dituntut untuk dapat menemukan hal-hal yang baru dan dapat berkreativitas dari pelaksanaan praktikum. Dari keempat indikator yang dinilai, terlihat kurangnya keinginan peserta didik untuk menemukan hal-hal baru dan berkreativitas saat pelaksanaan praktikum. Pada saat melakukan suatu percobaan atau pengamatan, apabila peserta didik menggunakan alat tidak seperti biasanya atau melakukan kegiatan yang berbeda dari temannya yang lain, maka peserta didik dapat mengembangkan kreativitasnya dalam mempermudah penyelesaian masalah atau menemukan data baru dengan benar.

Kualitas sikap ilmiah pada sikap berpikir terbuka dan kerjasama memiliki kriteria baik dengan persentase 63,07\%. Dari keempat indikator yang dinilai yaitu berpartisipasi aktif dalam kelompok, tidak merasa selalu benar, menghargai pendapat atau temuan orang lain, dan menerima saran dari teman, dapat diketahui bahwa keempat indikator tersebut sudah dilaksanakan oleh beebrapa peserta didik. Indikator yang harus ditingkatkan lagi yaitu pada indikator tidak merasa selalu benar. Pada saat proses pembelajaran, peserta didik dibiasakan untuk dapat menerima pendapat teman yang berbeda dan dapat mengubah pendapatnya apabila pendapat tersebut kurang tepat. Peserta didik perlu menyadari bahwa pengetahuan yang dimiliki orang lain mungkin lebih banyak daripada yang ia miliki. Oleh karena itu, peserta didik perlu bekerjasama dengan orang lain dalam rangka meningkatkan pengetahuannya.

Kualitas sikap ilmiah pada aspek ketekunan memiliki kriteria baik dengan persentase $68,63 \%$. Dari keempat indikator yang dinilai, indikator yang sangat jarang dilaksanakan oleh peserta didik yaitu pada indikator mengulangi percobaan meskipun berakibat kegagalan.

Kualitas sikap ilmiah pada aspek peka terhadap lingkungan sekitar memiliki kriteria baik dengan persentase $74,07 \%$. Pada aspek ini merupakan aspek dengan skor teringgi dari ketujuh aspek yang dinilai. Dari keempat indikator yang dinilai, peserta didik sudah mampu melaksanakan indikator-indikator tersebut seperti perhatian terhadap peristiwa sekitar, dapat berpartisipasi pada kegiatan sosial, menjaga kebersihan lingkungan sekolah, dan membersihkan alat serta bahan yang digunakan pada saat pelaksanaan praktikum. Pada aspek peka terhadap lingkungan sekitar, peserta didik dituntut untuk dapat meningkatkan rasa cinta dan kepekaannya terhadap lingkungan sekitar. Hal tersebut terbukti dari kegiatan praktikum yang dilaksanakan, terlihat peserta didik dapat menjaga ruangan laboratorium yang digunakan. Saat pelaksanaan praktikum berakhir, peserta didik langsung membersihkan ruangan laboratorium dan membersihkan alat serta bahan yang digunakan. 
Dari hasil analisis data angket dan lembar observasi didapatkan total ratarata persentase dan kriteria sikap ilmiah peserta didik dalam pelaksanaan praktikum pembelajaran IPA-Biologi Kelas VIII. Dari hasil analasis data tersebut dapat dilihat bahwa setiap aspek sikap ilmiah memiliki persentase yang berbeda-beda sehingga juga mempunyai kualitas sikap ilmiah yang berbeda, untuk skor tertinggi terdapat pada aspek peka terhadap lingkungan sekitar dan skor terendah terdapat pada aspek sikap berpikir kritis. Adapun urutan skor tertinggi hingga skor terendah dari ketujuh aspek sikap ilmiah yaitu aspek sikap peka terhadap lingkungan sekitar, aspek sikap ketekunan, aspek sikap rasa ingin tahu, aspek sikap berpikir terbuka, aspek sikap respek terhadap data, aspek sikap penemuan dan kreativitas, dan aspek sikap berpikir kritis. Maka, dapat diketahui bahwa sikap ilmiah peserta didik dalam pelaksanaan praktikum pembelajaran IPA-Biologi Kelas VIII mempunyai persentase 54,3237\%, sehingga kriteria dari sikap ilmiah peserta didik dari ketujuh aspek yang dinilai yaitu memiliki kriteria cukup.

Terdapat beberapa faktor yang menyebabkan perbedaan hasil persentase sikap ilmiah peserta didik dari penilaian angket angket dan lembar observasi. Faktor penyebabnya yaitu pada saat pengisian angket yang dilakukan oleh peserta didik, terdapat beberapa peserta didik yang tidak jujur terhadap kegiatan yang ia laksanakan saat praktikum berdasarkan butir pernyataan yang tersedia sehingga peserta didik lebih membenarkan diri pada saat pengisian angket. Menurut Probowati (2018:9), salah satu kelemahan dalam pengisian angket oleh peserta didik saat penilaian sikap ilmiah yaitu peserta didik tidak membaca seluruh butir pernyataan dengan sungguhsungguh. Selaras dengan pernyataan tersebut, faktor penyebab berikutnya yaitu peserta didik tidak seluruhnya membaca angket dengan baik, hal ini terlihat bahwa peserta didik hanya menggunakan waktu yang sedikit saat menjawab butir pernyataan angket yang berjumlah 56 pernyataan. Dari beberapa faktor tersebut, penilaian menggunakan instrumen lembar observasi sangat membantu mendukung hasil penilaian dari aspek sikap-aspek sikap ilmiah yang memang dilakukan oleh peserta didik saat pelaksanaan praktikum.

\section{PENUTUP}

Berdasarkan hasil penelitian dan pembahasan yang dipaparkan dapat disimpulkan, bahwa rincian kualitas sikap ilmiah pada setiap aspek yaitu pada aspek sikap rasa ingin tahu memiliki kriteria baik, aspek sikap respek terhadap data memiliki kriteria cukup, aspek berpikir kritis memiliki kriteria cukup, aspek penemuan dan kreativitas memiliki kriteria cukup, aspek berpikir terbuka dan kerjasama memiliki kriteria baik, aspek ketekunan memiliki kriteria baik, dan aspek peka terhadap lingkungan sekitar memiliki kriteria baik. Jadi, kualitas sikap ilmiah peserta didik dalam pelaksanaan praktikum pembelajaran IPA-Biologi peserta didik Kelas VIII SMPN 34 Padang memperoleh kriteria cukup. 


\section{REFERENSI}

Farooq, M. 2012. Measurement Of Scientific Attitude Of Secondary School Students In Pakistan. Academic Research International. 2(2), 379-392.

Nasution, S. P. 2014. Efektifitas Pembelajaran Berbasis Praktikum Terhadap Keterampilan Proses Sains dan Sikap Ilmiah Siswa. Jurnal Pendidikan Biologi FKIP Unila. 1-13.

Probowati, A. 2018. Sikap Ilmiah Siswa Pada Praktikum Biologi Kelas XI IPA SMAN 2 Surakarta Tahun Pelajaran 2017/2018. Jurnal Pendidikan Biologi. $1-10$

Suryaningsih, Y. 2017. Pembelajaran Berbasis Praktikum Sebagai Sarana Siswa Untuk Berlatih Menerapkan Keterampilan Proses Sains Dalam Materi Biologi. Jurnal Bio Education. 2(2), 49-57.

Tala, S., \& Vesterinen, V. M. 2015. Nature of Science Contextualized: Studying Nature of Science with Scientists. Sci \& Educ. 1-23.

Tias, I. W. 2017. Penerapan Model Penemuan Terbimbing Untuk Meningkatkan Hasil Belajar IPA Siswa Sekolah Dasar. Dwijacendekia. 50-60. 